\title{
Value of the Radiological Study of the Thorax for Diagnosing Left Ventricular Dysfunction in Chagas' Disease
}

\author{
Amanda Arantes Perez, Antonio Luiz Pinho Ribeiro, Márcio Vinícius Lins Barros, \\ Marcos Roberto de Sousa, Roberto José Bittencourt, Fernando Santana Machado, \\ Manoel Otávio Costa Rocha
}

Belo Horizonte, MG - Brazil

\begin{abstract}
Objective - To determine the value of the radiological study of the thorax for diagnosing left ventricular dilation and left ventricular systolic dysfunction in patients with Chagas' disease.
\end{abstract}

Methods - A cross-sectional study of 166 consecutive patients with Chagas' disease and no other associated diseases. The patients underwent cardiac assessment with chest radiography and Doppler echocardiography. Sensitivity, specificity, and positive and negative predictive values of chest radiography were calculated to detect left ventricular dysfunction and the accuracy of the cardiothoracic ratio in the diagnosis of left ventricular dysfunction with the area below the ROC curve. The cardiothoracic ratio was correlated with the left ventricular ejection fraction and the left ventricular diastolic diameter.

Results - The abnormal chest radiogram had a sensitivity of $50 \%$, specificity of $80.5 \%$, and positive and negative predictive values of $51.2 \%$ and $79.8 \%$, respectively, in the diagnosis of left ventricular dysfunction. The cardiothoracic ratio showed a weak correlation with left ventricular ejection fraction $(r=-0.23)$ and left ventricular diastolic diameter $(r=0.30)$. The area calculated under the ROC curve was 0.734 .

Conclusion - The radiological study of the thorax is not an accurate indicator of left ventricular dysfunction; its use as a screening method to initially approach the patient with Chagas' disease should be reevaluated.

Key words: chest radiography, left ventricular dysfunction, Chagas' disease

Hospital das Clínicas da Faculdade de Medicina da UFMG and Ecoar - Medicina Diagnóstica

Mailing address: Antonio Luiz Pinho Ribeiro - Rua Campanha, 98/101 - 30310770 - Belo Horizonte, MG, Brazil - E-mail: antonior@ net.em.com.br

English version by Stela Maris C. e Gandour
Chagas' disease currently affects 20 million individuals in Latin America ${ }^{1}$. In Brazil, approximately 5 million chagasic patients exist ${ }^{1,2}$. Chagas' disease has a wide variety of clinical presentations, ranging from completely asymptomatic individuals, who represent the great majority of the patients, to others with severe, sometimes fatal, cardiac alterations. Of the indicators of a poor prognosis, left ventricular dysfunction stands out as the major predictor of morbidity and mortality ${ }^{3-7}$.

The radiological study of the thorax is a routine investigative method to initially assess patients with Chagas' disease, aiming at detecting cardiac impairment and at characterizing the clinical form of the disease. ${ }^{8}$ In other cardiac diseases, however, conventional radiography of the thorax is known not to allow an accurate assessment of the degree of ventricular dysfunction ${ }^{9,10}$.

We determined the value of the radiological study of the thorax in the diagnosis of left ventricular dilation and left ventricular systolic dysfunction on Doppler echocardiography of patients with Chagas' disease. The prevalence of echocardiographic and electrocardiographic alterations predictive of a worse prognosis in patients with a normal and enlarged cardiac silhouette was also determined.

\section{Methods}

To determine the value of chest radiography for detecting left ventricular dilation and left ventricular systolic dysfunction in patients with Chagas' disease, we carried out a cross-sectional study on 166 consecutive patients with Chagas' disease, whose ages ranged from 21 to 70 years. The patients were selected from the Referral Outpatient Care Unit for Chagas' Disease of the Hospital das Clínicas of the Universidade Federal de Minas Gerais and in the "Orestes Diniz" Training and Referral Center for Infectious and Parasitic Diseases according to inclusion and exclusion criteria from January 1998 to July 1999. 
Individuals with positive serology for Trypanossoma cruzi according to 2 different techniques or more, including indirect immunofluorescence, indirect hemagglutination, and ELISA were considered chagasic.

The exclusion criteria were as follows: 1) impossibility or no availability to perform the examinations; 2) systemic arterial hypertension, operationally defined as blood pressure $\geq 160 / 95 \mathrm{mmHg}$, or use of hypotensive drugs; 3 ) history compatible with coronary heart disease, according to clinical evaluation; 4) previous episode suggestive of acute rheumatic disease; 5) diabetes mellitus or reduced tolerance to glucose, according to the definition of the $\mathrm{Na}$ tional Diabetes Data Group; 6) thyroid dysfunction manifested as abnormal levels of thyroid stimulating hormone (TSH) and free thyroxin $\left(\mathrm{T}_{4} \mathrm{~F}\right) ; 7$ ) renal failure, defined as an increase in the serum levels of creatinine $(>1.2 \mathrm{mg} / \mathrm{dL}$ for females and $>1.5 \mathrm{mg} / \mathrm{dL}$ for males) and urea $(>36 \mathrm{mg} / \mathrm{dL}$ for females and $>42 \mathrm{mg} / \mathrm{dL}$ for males); 8) chronic obstructive pulmonary disease, according to the presence of suggestive history, physical examination, electrocardiogram, and radiological alterations; 9) electrolytic and fluid disorders (serum levels of sodium $>145 \mathrm{mg} / \mathrm{dL}$ and serum levels of potassium $>5.5 \mathrm{mg} / \mathrm{dL}$ ); 10) significant anemia defined as hemoglobin $<10 \mathrm{~g} / \mathrm{dL} ; 11$ ) alcoholism, defined as a mean week consumption above $420 \mathrm{~g}$ of ethanol (daily mean $>60 \mathrm{~g}$ of ethanol); 12) any other acute or chronic significant systemic disease; 13) pregnancy defined by the laboratory finding of plasma levels of chorionic gonadotropin $>5$ mUImL; and 14) presence of atrial fibrillation or implanted pacemaker.

All individuals selected underwent complementary investigations, which comprised chest radiography in posteroanterior and lateral views and Doppler echocardiography. The examinations proposed were performed with the written informed consent of all patients taking part in the study, which was approved by the Committee on Ethics in Research of the Federal University of Minas Gerais (UFMG). The well being and rights of all patients studied were considered.

Chest radiography was performed according to the conventional technique at the Radiological Unit of the Hospital das Clínicas of the UFMG and analyzed by one observer who ignored the echocardiographic findings. The cardiac silhouette and the cardiothoracic ratio were assessed. The cardiothoracic ratio was obtained by the relation between the transverse diameter of the heart and the transverse diameter of the thorax at the level of the right diaphragmatic cupula. The transverse diameter of the heart was calculated by adding the greatest segment obtained in the cardiac area to the right of the central axis $\left(\mathrm{T}_{1}\right)$ and the greatest segment obtained in the cardiac area to the left of the central axis $\left(\mathrm{T}_{2}\right)$ (fig. 1).

The echocardiographic parameters were obtained by an experienced echocardiographer, who ignored the findings of the chest radiography, and used HDI 5000 equipment. The measurements of the M mode and of the contractility of the regional wall were performed according to the recommendations of the American Society of Echocardiography ${ }^{11}$. The

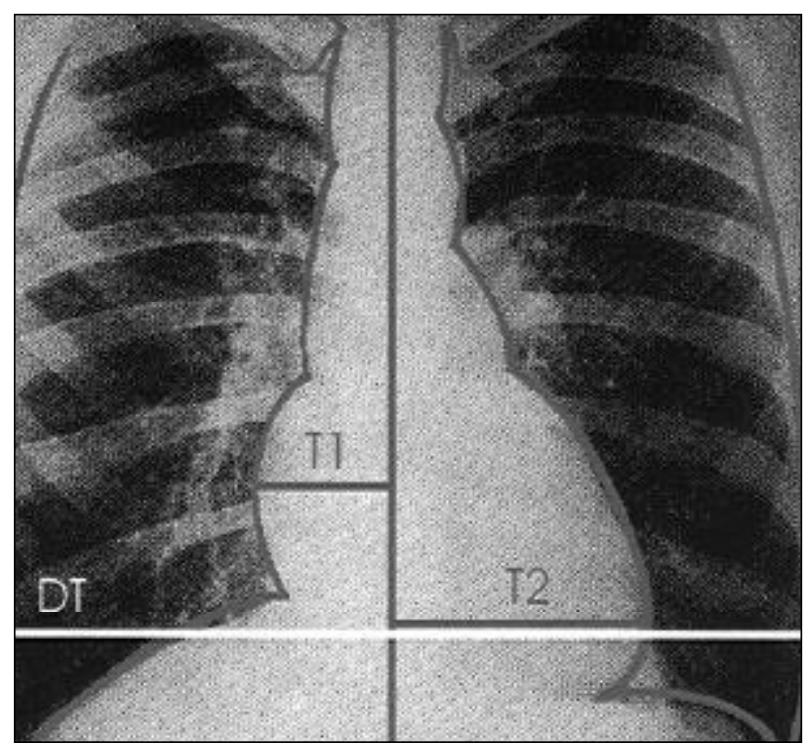

Fig. 1 - Conventional chest radiography. The cardiothoracic ratio was obtained dividing the transverse diameter of the heart by the transverse diameter of the thorax at the level of the right diaphragmatic cupula. The transverse diameter of the heart was calculated by adding the greatest segment obtained in the cardiac area to the right of the central axis $\left(\mathrm{T}_{1}\right)$ and the greatest segment obtained in the cardiac area to the left of the central axis $\left(\mathrm{T}_{2}\right)$.

ejection fraction was obtained with the Simpson method (fig. 2 ), and the score of motility of the left ventricular wall was obtained by using the model of 16 segments.

Left ventricular dysfunction was defined by the presence of left ventricular dilation (left ventricular diastolic diameter $>55 \mathrm{~mm}$ ) or depressed ejection fraction (ejection fraction $<0.50$ ), or both, obtained on Doppler echocardiography.

The cardiac silhouette was classified as normal or enlarged based on the subjective analysis of the cardiac area observed on chest radiography in posteroanterior and lateral views. Chest radiography with a cardiothoracic ratio greater than 0.50 or an enlarged cardiac silhouette, or both, was considered abnormal.

The quantitative variables were described by the mean and standard deviation or the median and interquartile range; the qualitative variables were described by frequency. The correlation between them was obtained with the Spearman correlation coefficient. The patients with a significant discordance between the chest radiographic findings and those on Doppler echocardiography were identified and their cases were carefully reviewed. The normality test for quantitative variables (Ryan - Anderson) and the Bartlett test for homogeneity of variance were performed. In all tests, $\mathrm{p}<0.05$ was used for rejecting the null hypothesis.

The sensitivity, specificity, and positive and negative predictive values of the abnormal chest radiography on the diagnosis of left ventricular dysfunction were calculated. The performance of the different values of the cardiothoracic ratio on the detection of left ventricular dysfunction in patients with Chagas' disease was assessed with the ROC (receiver-operator-characteristic) curve. The area below the 
curve varies from zero to 1 and measures the accuracy of a diagnostic test. Considering 0.5 as the cut point established in the literature ${ }^{12,13}$, the sensitivity, specificity, and positive and negative predictive values of the cardiothoracic ratio on the diagnosis of left ventricular dysfunction were calculated.

The patients were divided into 2 groups according to the finding of normal or enlarged cardiac silhouette. In each group, the characteristics of the indices obtained on Doppler echocardiography (left ventricular diastolic diameter, ejection fraction, regional contractility, presence of aneurysm, and left ventricular diastolic function) and on electrocardiography (duration of the QRS complex, heart rate, presence of ventricular extrasystoles, and intraventricular blocks) were assessed. The cardiac silhouette was confronted with the cardiothoracic ratio. The comparisons were performed with ANOVA, the Kruskal-Wallis test or the Pearson chi-square test, depending on the type and distribution of the variable studied.

\section{Results}

The study comprised 166 patients with Chagas' disease, $55 \%$ of whom were males, and their ages ranged from 21 to 70 (mean $=42.6)$ years. Forty-eight $(29 \%)$ patients had left ventricular dysfunction.

The abnormal chest radiogram had a sensitivity of $50 \%$, specificity of $80.5 \%$, and positive and negative predictive values of $51.2 \%$ and $79.8 \%$, respectively, in diagnosing left ventricular dysfunction.

The cardiothoracic ratio correlated weakly with the ejection fraction $(\mathrm{r}=-0,23 ; 95 \% \mathrm{CI}=-0.37$ to $-0.08 ; \mathrm{p}<0.05)$ and with the left ventricular diastolic diameter $(r=0.30 ; 95 \%$

\begin{tabular}{|c|c|c|c|}
\hline \multicolumn{4}{|c|}{$\begin{array}{c}\text { Table I - General, echocardiographic, electrocardiographic, and } \\
\text { radiological characteristics of chagasic patients with normal and } \\
\text { enlarged cardiac silhouette }\end{array}$} \\
\hline & Normal silhouette $\mathrm{E}$ & Enlarged silhouette & $\mathrm{P}$ \\
\hline Absolute number & 119 & 47 & \\
\hline Age (years)\# & $41.9 \pm 9.0$ & $45.9 \pm 10.6$ & 0.02 \\
\hline Males & 57 & 50 & 0.54 \\
\hline $\operatorname{LVd}(\mathrm{mm})^{*}$ & $50(29-74)$ & 55 (46-77) & $<0.01$ \\
\hline $\mathrm{LVd}>55 \mathrm{~mm}$ & 19 & 49 & $<0.01$ \\
\hline $\mathrm{EF}(\%)^{*}$ & $62(26-69)$ & $57(23-72)$ & $<0.01$ \\
\hline $\mathrm{EF}<.50$ & 11 & 43 & $<0.01$ \\
\hline LVD & 20 & 51 & $<0.01$ \\
\hline Aneurysm & 18 & 28 & 0.27 \\
\hline Score $*$ & $1.00(1-2.61)$ & $1.31(1-2.81)$ & $<0.01$ \\
\hline Diastolic dysfunction & 8 & 33 & $<0.01$ \\
\hline HR \# & $64.1 \pm 11.7$ & $62.5 \pm 10.7$ & 0.74 \\
\hline QRS (ms)\# & $0.095 \pm 0.024$ & $0.119 \pm 0.030$ & $<0.01$ \\
\hline VES & 7 & 19 & 0.01 \\
\hline RBBB & 19 & 55 & $<0.01$ \\
\hline $\mathrm{CTR}^{*}$ & $0.44(0.34-0.49)$ & $0.52(0.42-0.52)$ & $<0.01$ \\
\hline \multicolumn{4}{|c|}{$\begin{array}{l}\text { Data in percentages, except \# mean } \pm \mathrm{SD} \text {, and } * \text { median (minimum and } \\
\text { maximum). LVd- left ventricular diastolic diameter; EF- ejection fraction; } \\
\text { LVD- left ventricular dysfunction; aneurysm = aneurysm of the left ventricular } \\
\text { apex; score = score of the motility of the left ventricular wall; HR- heart rate; } \\
\text { QRS- duration of the QRS complex; VES- ventricular extrasystoles; RBBB- } \\
\text { right bundle-branch block; CTR = cardiothoracic ratio. }\end{array}$} \\
\hline
\end{tabular}

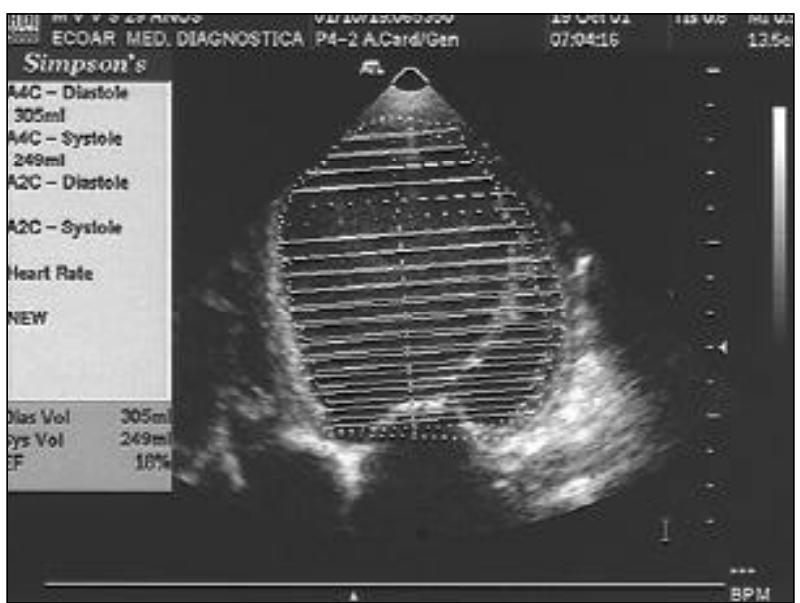

Fig. 2 - The ejection fraction was obtained with the Simpson's method.

$\mathrm{CI}=0.15$ to $0.43 ; \mathrm{p}<0.05$ ) (fig. 3 ). The cardiothoracic ratio greater than 0.5 showed sensitivity of $41.7 \%$, specificity of $88.1 \%$, and positive and negative predictive values of $58.9 \%$ and $78.7 \%$, respectively, in detecting left ventricular dysfunction. The area calculated under the ROC curve was $0.734 \pm 0.04$ (fig. 4).

The comparisons between the echocardiographic and electrocardiographic parameters of patients with normal and enlarged cardiac silhouette are shown in table I. The patients with Chagas' disease and an enlarged silhouette were significantly older than those with normal silhouette. The presence of left ventricular dysfunction was significantly more frequent in patients with an enlarged cardiac silhouette, and a similar pattern was observed for the presence of diastolic dysfunction and alterations in the segmentary contractility. A significant increase in the duration of the QRS complex was evident in patients with an enlarged cardiac area. The occurrence of ventricular extrasystoles and complete right bundle-branch block was significantly greater in the group of patients with an enlarged cardiac silhouette. On Doppler echocardiography, no significant difference was found between the 2 groups in regard to the presence of left ventricular aneurysms.

\section{Discussion}

The value of measuring cardiac size based on radiological film has decreased as compared with that based on Doppler echocardiography, which provides a more precise analysis of the diameter of the cardiac chambers and of the left ventricular function, and also other important functional data, such as evaluation of the diastolic function and segmentary contractility. Although cardiac size may be determined by chest radiography, many cardiac and extracardiac factors influence this measure, such as the examination technique, the patient's biotype, the patient's physiological status, thoracic alterations (scoliosis, pectus excavatum), the size of the lungs, the breathing phase, the cardiac cycle phase, and heart rate at the time of examination ${ }^{12,13}$. Therefore, chest radiography may only provide a raw and sub- 


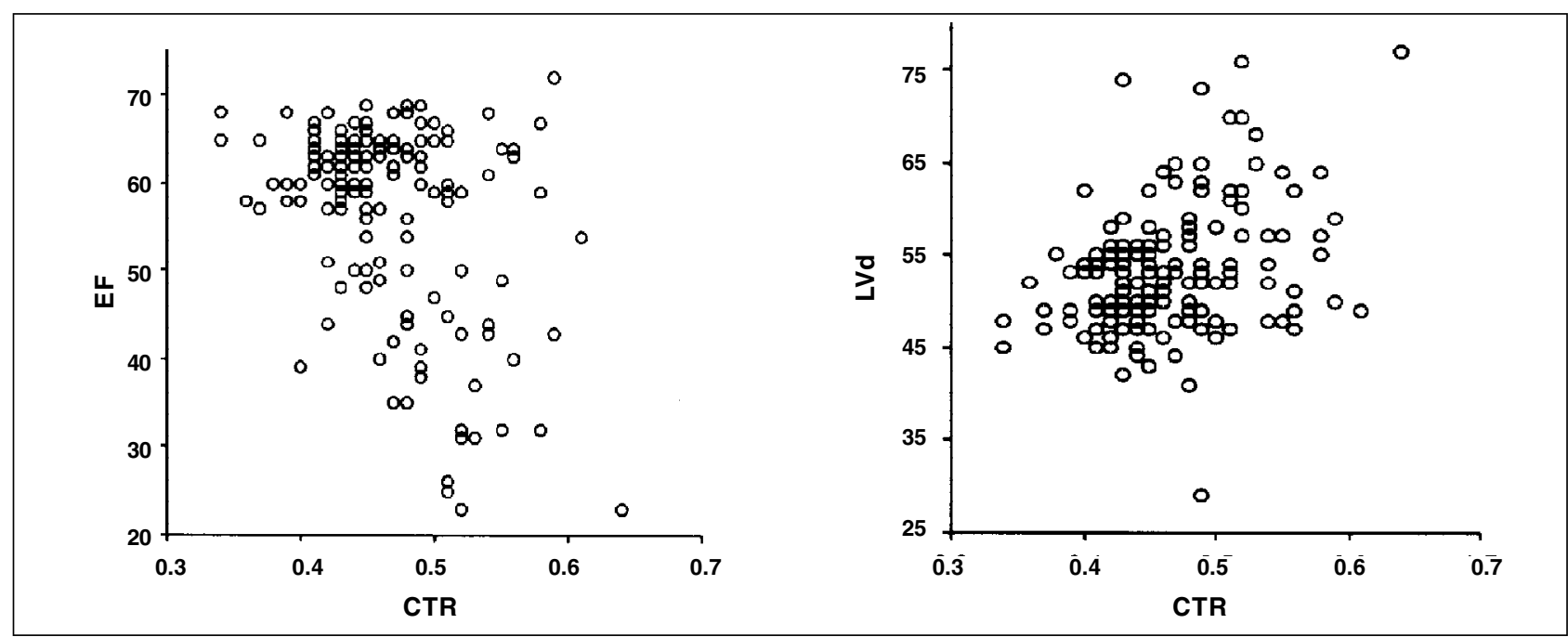

Fig. 3 - Correlation between the cardiothoracic ratio, the ejection fraction, and the left ventricular diastolic diameter.

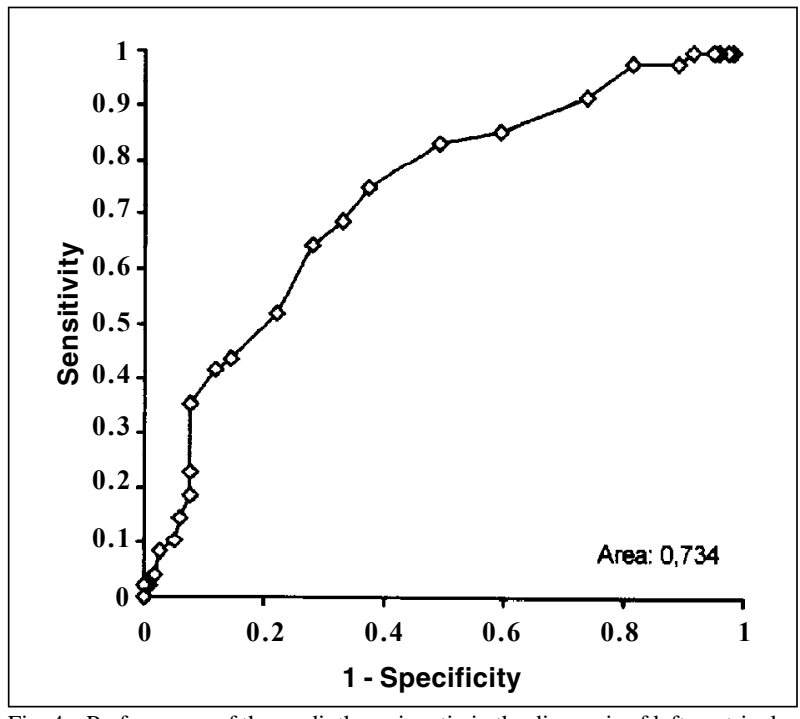

Fig. 4 - Performance of the cardiothoracic ratio in the diagnosis of left ventricular dysfunction in chagasic patients. Area under the ROC curve $=0.734$.

jective estimation of the cardiac size through the classification of the cardiac silhouette as normal or enlarged. More objective numerical parameters provided by noninvasive examinations, such as Doppler echocardiography, are required for an accurate estimation of the diameter of the cardiac chambers.

In this study, in accordance with the results obtained in patients with heart failure ${ }^{9,10}$, chest radiography alone was not an accurate indicator of the degree of left ventricular dysfunction in patients with Chagas' disease, although a weak and significant correlation has been observed between the cardiothoracic ratio and the left ventricular diastolic diameter $(r=0.30 ; \mathrm{p}<0.05)$ and between the cardiothoracic ratio and the ejection fraction $(r=-0.23 ; \mathrm{p}<0.05)$. These values are different from those of a previous study ${ }^{14}$, in which a clear correlation between the radiological and echocardiographic measurements in patients with Chagas' disease was observed. In that study ${ }^{14}$, a small sample of 22 patients was divided into 2 different groups according to the cardiac size obtained on radiological imaging. Samples representing extreme values of cardiothoracic ratio and cardiac diameter were compared; patients with cardiothoracic ratio near the maximum limit, which is considered normal in the literature ${ }^{12,13}$, were not assessed. In addition, the authors ${ }^{14}$ considered a cardiothoracic ratio of 0.5 as abnormal, contrary to the maximum limit value adopted for the cardiothoracic ratio in our study ${ }^{12,13}$.

Conventional chest radiography and electrocardiography are the initial investigation techniques used in a patient with Chagas' disease to assess cardiac impairment and to characterize the clinical form of the disease ${ }^{15}$. Absence of alterations on chest radiography is required to characterize the chronic undetermined form of Chagas' disease ${ }^{8}$, even knowing that, if assessed on more refined methods, these patients may have significant cardiac alterations ${ }^{16}$. However, in our study, chest radiography had a low sensitivity $(50 \%)$ for detecting left ventricular dilation and left ventricular systolic dysfunction, in addition to a negative predictive value lower than $80 \%$, having, therefore, limited value as a screening test. The overall performance of the cardiothoracic ratio was also limited, with an area under the ROC curve of 0.734 .

The presence of cardiac enlargement on radiography is a reliable indicator of left ventricular dysfunction as follows: a cardiothoracic ratio greater than 0.5 has a specificity of $88.1 \%$ and a positive predictive value of $58.9 \%$. In addition, an enlarged cardiac silhouette is associated with electrocardiographic and echocardiographic markers of cardiac impairment, such as the presence of right bundlebranch block and ventricular extrasystoles, although it does not relate to other significant abnormalities, such as the presence of ventricular aneurysm. Therefore, although inadequate for screening left ventricular dysfunction, chest radiological study plays an important role in the clinical assessment of patients with Chagas' disease and defined 
heart disease. In addition to providing elements about the pulmonary circulation in patients with heart failure, a significantly enlarged cardiac silhouette is an indicator of the severity of the disease and of a worse prognosis ${ }^{5}$.

Left ventricular dysfunction is the major prognostic factor in Chagas' disease ${ }^{3-7}$. Identification of the group of individuals with left ventricular dysfunction among the numerous populations of patients with Chagas' disease is a challenge in clinical practice. These individuals are candidates for preventive treatment with angiotensin-converting enzyme inhibitors, which can delay the appearance of symptoms and reduce mortality in the presence of left ventricular dysfunction ${ }^{17}$. Although the beneficial effects of these drugs on the survival of patients with Chagas' heart disease have not been formally tested, their beneficial clinical and hemodynamic effects on patients with Chagas' heart disease are evident ${ }^{18,19}$. In addition, these drugs are indicated in all patients with left ventricular dysfunction, symptomatic or not, independent of its etiology ${ }^{20}$.

The electrocardiogram is particularly useful for identifying the low-risk population, because a normal examination is associated with an excellent prognosis in the midterm ${ }^{21-23}$. The additional value of chest radiography in the initial assessment of patients with Chagas' disease and a normal electrocardiogram is questionable, because the examination has little sensitivity for detecting left ventricular dysfunction, the major indicator of risk in Chagas' disease. Currently, even echocardiography, although able to show abnormalities in segmentary contractility ${ }^{24}$ or more subtle alterations on Doppler tissue imaging ${ }^{25}$, seems to have its routine use questionable in this population with an excellent prognosis. On the other hand, because individuals with typical electrocardiographic alterations may have either depressed or within the normal range left ventricular systolic function, additional examinations are indicated to identify the presen- ce of left ventricular dysfunction. Considering the insufficient diagnostic performance of chest radiography, echocardiography appears to be one method of choice for the subsequent evaluation of cardiac impairment in patients with abnormal electrocardiographic findings, allowing the stratification of patients into high- and low-risk groups and the selection of candidates for therapy with angiotensinconverting enzymeinhibitors ${ }^{23}$. However, some limitations of echocardiography should be considered, especially the difficulty in performing the examination in rural areas where the disease is endemic, the existence of patients without an adequate window for the examination, and the need for an experienced examiner. Measurement of the type B natriuretic peptide is an important marker of left ventricular dysfunction in nonchagasic patients ${ }^{26}$, and it may also be a useful tool in the initial evaluation of patients with Chagas' disease. Data obtained in our study indicate that the method has an excellent diagnostic performance in detecting left ventricular dysfunction in chagasic patients ${ }^{27}$. Because of the high prevalence of Chagas' disease among us, cost-benefit studies could quantify the medical, social, and economic impact of the application of different approaches in the initial evaluation of these patients.

In conclusion, although specific, chest radiography has little sensitivity in diagnosing left ventricular systolic dysfunction; its use as a screening method in the initial approach to patients with Chagas' disease should be reevaluated.

\section{Acknowledgements}

We thank the National Council on Scientific and Technological Development (Conselho Nacional de Desenvolvimento Científico e Tecnológico - CNPq) and the Dean of Research at the UFMG (Pró-Reitoria de Pesquisa da UFMG).

\section{References}

1. WHO Expert Committee on the Control of Chagas Disease. Control of Chagas Disease 1991: 1-95.

2. Dias JCP. Situación actual de la enfermedad de Chagas en las Américas. In: Madoery R, Madoery C, Cámera ML, editors. Actualizaciones en la Enfermedad de Chagas. Buenos Aires: Congresso Nacional de Medicina, 1993: 1-29.

3. Hagar JM, Rahimtoola SH. Chagas' heart disease in the United States. N Engl J Med 1991; 325: 763-8.

4. Espinosa RA, Pericchi LR, Carrasco HA, Escalante A, Martinez O, González R. Prognostic indicators of chronic chagasic cardiopaphy. Int J Cardiol 1991; 30: 195-202.

5. Carrasco HA, Parada H, Guerrero L, Duque M, Durán D, Molina C. Prognostic implications of clinical, eletrocardiographic and hemodynamic findings in chronic Chagas'disease. Int J Cardiol 1994; 43: 27-38.

6. Mady C, Cardoso RHA, Barreto ACP, Luz PL, Bellotti G, Pileggi F. Survival and predictors of survival in patients with congestive heart failure due to Chagas' cardiomypathy. Circulation 1994; 90: 3098-102.

7. Bestetti RB, Dalbo CMR, Freitas OC, Teno LAC, Castilho OT, Oliveira JSMO Noninvasive predictors of mortality for patients with Chagas' heart disease. A multivariate stepwise logistic regression study. Cardiology 1994; 84: 261-7.

8. Reunião de Pesquisa Aplicada em Doença de Chagas. Validade do conceito de forma crônica indeterminada de doença de Chagas. Rev Soc Bras Med Trop 1985; 18: 46.

9. Clark AL, Coats AJ. Unreliability of cardiothoracic ratio as a marker of left ventri- cular impairment: comparison with radionuclide ventriculography and echocardiography. Postgrad Med J 2000; 76: 289-91.

10. Philbin EF, Garg R, Danisa K, et al. The relationship between cardiothoracic ratio and left ventricular ejection fraction in congestive heart failure. Arch Intern Med 1998; 158: 501-6.

11. Schiller NB, Shah PM, Crawford M, et al. Recommendations for quantitation of the left ventricle by two-dimensional echocardiography. American Society of Echocardiography Committee on Standards, Subcommittee on Quantitation of TwoDimensional Echocardiograms. J Am Soc Echocardiography 1989; 2: 358-67.

12. Steiner RM, Levin DC. Radiology of the heart. In: Braunwald E, editor. Heart disease. 4thed. Philadelphia: WB Saunders Co., 1992: 204-34.

13. The Criteria Committee of the New York Heart Association. Nomenclature and criteria for diagnosis of diseases of the heart and great vessels. $9^{\text {th }}$ ed. New York: Copyright, 1994: 259-63.

14. Pereira-Barreto AC, Mady C, Arteaga-Fernandez E, et al. Valor do índice cardiotorácico na avaliação do comprometimento miocárdico. Correlação com avaliação ecocardiográfica. Rev Hosp Clin Fac Med S Paulo 1983; 38: 40-5.

15. Rassi Jr A, Marin-Neto JA. Estado da Arte - Cardiopatia chagásica crônica. Rev Soc Cardiol Estado de São Paulo 2000; 10: 6-32.

16. Ribeiro ALP, Rocha MOC. Forma indeterminada da doença de Chagas: considerações acerca do diagnóstico e do prognóstico. Rev Soc Bras Med Trop 1998; 31: 301-14.

17. Effect of enalapril on mortality and the development of heart failure in asympto- 
matic patients with reduced left ventricular ejection fractions. The SOLVD Investigattors N Engl J Med 1992; 327: 685-91.

18. Roberti RR, Martinez EE, Andrade JL, et al. Chagas cardiomyopathy and captopril. Eur Heart J 1992; 13: 966-70.

19. Khoury AM, Davila DF, Bellabarba G, et al. Acute effects of digitalis and enalapril on the neurohormonal profile of chagasic patients with severe congestive heart failure. Int J Cardiol. 1996; 57: 21-9.

20. Hunt SA, Baker DW, Chin MH, et al. ACC/AHA guidelines for the evaluation and management of chronic heart failure in the adult: a report of the American College of Cardiology/American Heart Association Task Force on Practice Guidelines (Committee to Revise the 1995 Guidelines for the Evaluation and Management of Heart Failure). Am Coll Cardiol, 2001. Web site disponível em http:// www.acc.org

21. Forichon E. Contribuition aux estimation de morbiditê et de mortalité dans la maladie de Chagas (Trypanosomose américaine). Rev Patol Trop 1975; 1: 57-78.

22. Maguire JH, Hoff R, Sherlock I, et al. Cardiac morbidity and mortality due to
Chagas' disease: prospective electrocardiographic study of a Brazilian community. Circulation 1987; 75: 1140-5.

23. Xavier SS, Sousa AS, Borges-Pereira J, Hasslocher-Moreno A. Nova proposta de classificação do acometimento cardíaco na fase crônica da doença de Chagas. Rev Soc Bras Med Trop 1999; 32: 121.

24. Ortiz J, Barretto AC, Matsumoto AY, et al. Alteração contrátil segmentar na forma indeterminada da Doença de Chagas. Estudo ecocardiográfico. Arq Bras Cardiol 1987; 49: 217-20.

25. Barros MV, Rocha MO, Ribeiro AL, Machado FS. Doppler tissue imaging to evaluate early myocardium damage in patients with undetermined form of Chagas' disease and normal echocardiogram. Echocardiography 2001; 18: 131-6.

26. McDonagh TA, Robb SD, Murdoch DR, et al. Biochemical detection of left-ventricular systolic dysfunction. Lancet 1998; 351: 9-13.

27. Ribeiro ALP, Reis AM, Barros MVL, et al. Brain natriuretic peptide in the diagnosis of systolic left ventricular dysfunction in Chagas disease. Lancet 2002; 360: 461-2.

Bula resumida - MICARDIS ${ }^{\circledR}$ Telmisartam - Uso adulto - Forma farmacêutica e apresentações: Comprimidos de $40 \mathrm{mg}$ : embalagens com 14 e 28 comprimidos. Comprimidos de $80 \mathrm{mg}$ : embalagens com 14 e 28 comprimidos. Composição: Cada comprimido contém $40 \mathrm{mg}$ ou $80 \mathrm{mg}$ de telmisartam. Excipientes q.s.p. 1 comprimido. Indicações: Tratamento da hipertensão arterial, como monoterapia ou em associação com comprimidos. Composição: Cada comprimido contem $40 \mathrm{mg}$ ou $80 \mathrm{mg}$ de telmisartam. Excipientes q.s.p. 1 comprimido. Indicaçoes: Tratamento da hipertensão arterial, como monoterapia ou em associação com outros agentes anti-hipertensivos. Contra-indicações: Hipersensibilidade ao ingrediente ativo ou aos excipientes. Gravidez e lactação. Obstrução biliar. Disfunção hepática ou renal grave. Intolerância hereditária à frutose. Precauçães: Hipertensão renovascular: pacientes com estenose arterial renal bilateral ou estenose da artéria com um único rim funcionando: risco aumentado de hipotensão grave e insuficiência renal. Disfunção renal ou transplante hepático: monitoração periódica dos níveis séricos de potássio e creatinina. Não há experiência em pacientes com transplante renal recente. Desidratação: hipotensão
sintomática, especialmente após a primeira dose, pode ocorrer em pacientes que têm volemia e/ou sódio depletado, o que deve ser corrigido antes do início da terapêutica com MICARDIS. Outras condições de estimulação do SRAA e condições dependentes da atividade SRAA (insuficiência cardíaca congestiva grave): hipotensão aguda, hiperazotemia, oligúria ou, raramente, insuficiência renal aguda. Hiperaldosteronismo primário: não se recomenda o uso de MICARDIS. Estenose valvar aórtica e mitral e cardiomiopatia hipertrófica obstrutiva: Recomenda-se precaução especial. Hipercalemia: recomendase monitoração adequada dos níveis séricos de potássio em pacientes de risco. Diuréticos poupadores de potássio, suplementos de potássio, sais de potássio ou outros medicamentos que podem aumentar os níveis de potássio, como a heparina: podem levar a um aumento da potassemia. Portanto, nestas situações MICARDIS deve ser administrado com cautela. Distúrbios hepatobiliares: pode-se esperar redução da depuração em pacientes com disfunções obstrutivas do sistema biliar ou insuficiência hepática, pois a eliminação da droga é principalmente biliar. Intolerância à frutose: os comprimidos de MICARDIS contém sorbitol; portanto, é inadequado para pacientes com intolerância hereditária à frutose. Outros: menor eficácia na redução da pressão arterial na população negra do que na população não-negra. Cardiopatia isquêmica ou doença cardiovascular isquêmica pode resultar em infarto do miocárdio. Interações medicamentosas: MICARDIS pode aumentar o efeito hipotensor de outros agentes anti-hipertensivos. Observouse um aumento de $20 \%$ da concentração plasmática média de digoxina. Relataram-se aumentos reversíveis das concentrações séricas de lítio e de toxicidade; portanto, recomenda-se cuidadosa monitoração do uso concomitante com lítio. Gravidez e lactação: Contra-indicado. Reações adversas: As reações adversas à droga obtidas a partir de todos os estudos clínicos com telmisartam foram: Infecções do trato urinário, infecções do trato respiratório superior, ansiedade, visão anormal, vertigem, dor abdominal, diarréia, boca seca, dispepsia, flatulência, dor de estômago, eczema, aumento de suor, artralgia, dor nas urinário, infecções do trato respiratório superior, ansiedade, visão anormal, vertigem, dor abdominal, diarréia, boca seca, dispepsia, flatulência, dor de estômago, eczema, aumento de suor, artralgia, dor nas prurido, desmaio, insônia, depressão, vômito, hipotensão, bradicardia, taquicardia, dispnéia, eosinofilia, trombocitopenia, fraqueza e perda de eficácia. Relataram-se casos isolados de angioedema, urticária e outros eventos relacionados. Investigações: Raramente, observaram-se diminuição na hemoglobina ou aumento no ácido úrico. Observaram-se aumentos na creatinina ou nas enzimas hepáticas. Efeitos na habilidade de dirigir e utilizar máquinas: Ainda não se realizaram estudos específicos. Contudo, ao dirigir ou operar máquinas, pode ocasionalmente ocorrer tontura ou sonolência. Posologia: A dose recomendada é de $40 \mathrm{mg}$ uma vez ao dia. Alguns pacientes podem apresentar benefício com dose diária de $20 \mathrm{mg}$. Em casos em que a pressão arterial pretendida não seja atingida, a dose de MICARDIS pode ser aumentada para no máximo $80 \mathrm{mg}$ uma vez ao dia. Alternativamente, MICARDIS pode ser usado em combinação com diuréticos tiazídicos, como a hidroclorotiazida, para se obter uma redução maior da pressão arterial. Quando se considerar um aumento da dose, deve-se levar em conta que o máximo efeito anti-hipertensivo é geralmente atingido quatro a oito semanas após o início do tratamento. MICARDIS pode ser administrado com ou sem alimento. Insuficiência renal: Não há necessidade de ajustes de dose em pacientes com insuficiência renal leve a moderada. Telmisartam não é removido do sangue por hemofiltração. Insuficiência hepática: Nos pacientes portadores de insuficiência hepática leve a moderada, não se deve exceder a dose diária de 40 mg. Pacientes idosos: Não são necessários ajustes de doses e Farmacêutica Ltda.

Bula resumida - MICARDIS ${ }^{\oplus}$ HCT - Telmisartam/Hidroclorotiazida - Uso adulto - Composição: Cada comprimido de MICARDIS HCT contém $40 \mathrm{mg} / 12,5 \mathrm{mg}$ ou $80 \mathrm{mg} / 12,5 \mathrm{mg}$ de telmisartam/hidroclorotiazida. Embalagens com 14 e 28 comprimidos. Excipientes q.s.p. 1 comprimido. Indicações: Tratamento da hipertensão arterial. MICARDIS HCT, como associação de dose fixa, é indicado em pacientes cuja pressão arterial não é adequadamente controlada com telmisartam ou hidroclorotiazida isoladamente. Posologia: MICARDIS HCT deve ser administrado uma vez ao dia. A dose de MICARDIS pode ser aumentada gradativamente antes de substitúi-lo pelo MICARDIS HCT. A substituição direta da monoterapia pelas combinações fixas pode ser considerada. MICARDIS HCT 40/12,5 mg pode ser administrado em pacientes cujas pressões sangüíneas não sejam adequadamente controladas por MICARDIS $40 \mathrm{mg}$ ou hidroclorotiazida. MICARDIS HCT 80/12,5 mg pode ser administrado em pacientes cujas pressões arteriais não sejam adequadamente controladas por MICARDIS $80 \mathrm{mg}$ ou por MICARDIS HCT 40/12,5 mg. O máximo efeito anti-hipertensivo é obtido após 4 a 8 semanas de tratamento. Quando necessário, MICARDIS HCT pode ser administrado com outros anti-hipertensivos. MICARDIS HCT pode ser administrado com ou sem alimento. Devido ao componente hidroclorotiazida, MICARDIS HCT não deve ser usado em pacientes com disfunção renal grave. Nos casos leves a moderados, não se observaram efeitos adversos renais e não é necessário ajuste de dose. Recomenda-se monitoração periódica da função renal. Nos casos de insuficiência hepática leve a moderada, não se deve exceder a dose de 40/12,5 mg uma vez ao dia. MICARDIS HCT não é indicado em pacientes com insuficiência hepática grave. Não são necessários ajustes de dose conforme a idade. Ainda não se estabeleceram a segurança e a eficácia de MICARDIS HCT em pacientes menores de 18 anos. Contra-indicações: Hipersensibilidade aos componentes ativos, excipientes ou substâncias derivadas de sulfonamidas (como HCT). Gravidez e lactação. Colestase e distúrbios obstrutivos biliares. Insuficiência hepática ou renal grave (depuração de creatinina <30 $\mathrm{ml} / \mathrm{min}$ ). Hipopotassemia refratária e hipercalcemia. Precauções: Não utilizar nos casos de colestase, distúrbios biliares obstrutivos ou insuficiência hepática grave. Usar com cautela nos casos de função hepática Hipopotassemia refratária e hipercalcemia. Precauçoes: Não utilizar nos casos de colestase, distúrbios biliares obstrutivos ou insuficiência hepática grave. Usar com cautela nos casos de função hepática ser administrado em pacientes portadores de disfunção renal grave. Não há experiência quanto à administração de MICARDIS HCT em pacientes com grave insuficiência renal ou com um rim transplantado ser administrado em pacientes portadores de disfunção renal grave. Não há experiência quanto à administração de MICARDIS HCT em pacientes com grave insuficiência renal ou com um rim transplantado recentemente. Recomenda-se a monitoração periódica dos níveis séricos de potássio, creatinina e ácido úrico. A azotemia associada a diuréticos tiazídicos pode ocorrer em pacientes com função renal alterada. drogas que afetem o sistema renina-angiotensina-aldosterona foram associados com hipotensão aguda, hiperazotemia, oligúria ou, raramente, insuficiência renal aguda. Aldosteronismo primário: não s recomenda o uso de telmisartam, precaução especial em estenose valvar aórtica ou mitral e cardiomiopatia hipertrófica obstrutiva. Como tiazidas podem prejudicar a tolerância à glicose, pode ser necessário ajuste no tratamento em diabéticos e pode ocorrer manifestação de diabetes latente. A hidroclorotiazida aumenta os níveis de colesterol e triglicérides; contudo, nenhum ou poucos efeitos adversos foram relatados na dose de 12,5 mg contida em MICARDIS HCT. Pode ocorrer hiperuricemia ou precipitação de gota devido a hidroclorotiazida. Pode ser necessária monitoração periódica dos níveis séricos de eletrólitos, uma vez que a hidroclorotiazida pode causar desequilíbrio eletrolítico ou de fluidos (hipopotassemia, hiponatremia e alcalose hipoclorêmica). $\mathrm{O}$ tratamento concomitante com telmisartam pode reduzir a hipopotassemia induzida por diuréticos, devido aos efeitos antagônicos. Diuréticos poupadores de potássio, suplementos de potássio ou substitutos do sal contendo potássio devem ser utilizados concomitantemente com cautela. Não há evidências de que MICARDIS HCT reduza ou previna hiponatremia induzida por diuréticos. A deficiência de cloreto é geralmente leve. Tiazidas podem causar elevação dos níveis séricos de cálcio e magnésio. Interromper o uso antes dos testes de função da paratireóide. Não utilizar em intolerância hereditária à frutose. A redução excessiva da pressão arterial no caso de doença dos niveis sericos de cálcio e magnesio. Interromper o uso antes dos testes de função da paratireoide. Não utilizar em intolerância hereditária à frutose. A redução excessiva da pressão arterial no caso de doençąa cardiovascular isquêmica pode ser prejudicial. Relatou-se exacerbação ou ativação do lupus eritematoso sistêmico com o uso de hidroclorotiazida. Recomenda-se cautela no uso de anti-hipertensivos ao dirigi e operar máquinas. Interações medicamentosas: Relataram-se aumentos reversíveis das concentrações séricas de lítio durante administração concomitante com inibidores da enzima conversora de angiotensina. Relataram-se casos de interação com antagonistas dos receptores da angiotensina II. O risco de toxicidade por lítio pode ser aumentado com o uso de MICARDIS HCT. Recomenda-se a monitoração
dos níveis séricos de lítio durante o uso concomitante. O efeito de depleção de potássio da hidroclorotiazida é atenuado pelo efeito poupador de potássio do telmisartam, mas é potencializado por outros diuréticos caliuréticos, laxantes, corticosteróides, ACTH, anfotericina, carbenoxolona, penicilina G sódica, ácido salicílico e derivados. Por outro lado, o uso concomitante de diuréticos poupadores de potássio, suplementos/sais de potássio ou outras drogas podem aumentar os níveis séricos de potássio. Nesses casos, recomenda-se a monitoração dos níveis plasmáticos de potássio. Recomenda-se monitoração periódica de potássio na administração de MICARDIS HCT com digitálicos, antiarrítmicos e drogas que são conhecidamente indutoras de torsades de pointes. Telmisartam pode aumentar o efeito hipotensor de outros agentes anti-hipertensivos. Observou-se um aumento de $20 \%$ da concentração plasmática média de digoxina. Não se identificaram outras interações de importância clínica. Interações com a hidroclorotiazida: álcool, barbitúricos ou narcóticos (potencialização da hipotensão ortostática); drogas antidiabéticas (ajustes de dose podem ser necessários); metformina (risco de acidose láctica); colestiramina e resina colestipol (absorção de hidroclorotiazida é prejudicada); corticosteróides, ACTH (depleção eletrolítica, principalmente aumento de hipopotassemia); glicosídeos digitálicos (hipopotassemia ou hipomagnesemia induzida por tiazídicos favorece o aparecimento de arritmias cardíacas induzidas por digitálicos); drogas antiinflamatórias não-esteroidais (a administração de droga antiinflamatória não-esteroidal pode reduzir o efeito diurético, natriurético e anti-hipertensivo dos diuréticos tiazídicos em alguns pacientes). Os efeitos das aminas hipertensoras podem ser levemente antiinflamatoria näo-esteroidal pode reduzir o efeito diurético, natriurético e anti-hipertensivo dos diuréticos tiazídicos em alguns pacientes). Os efeitos das aminas hipertensoras podem ser levemente diminuídos. Os relaxantes musculares esqueléticos não-despolarizantes são potencializados pela hidroclorotiazida. Medicamentos uricosúricos podem requerer ajustes. Verificou-se aumento da incidência de reações de hipersensibilidade ao alopurinol. Os efeitos hiperglicêmicos dos beta-bloqueadores e diazóxido podem ser aumentados pelas tiazidas. Os agentes anticolinérgicos (por exemplo, atropina,
biperideno) podem aumentar a biodisponibilidade das tiazidas. As tiazidas podem aumentar os eventos adversos da amantadina. As tiazidas podem reduzir a excrę̧ão renal de drogas citotóxicas (por exemplo, biperideno) podem aumentar a biodisponibilidade das tiazidas. As tiazidas podem aumentar os eventos adversos da amantadina. As tiazidas podem reduzir a excreção renal de drogas citotóxicas (por exemplo,
ciclofosfamida, metotrexato). Gravidez e lactação: É contra-indicado. Se ocorrer gravidez, telmisartam deve ser descontinuado o mais breve possível. As tiazidas atravessam a barreira placentária e podem causar distúrbios eletrolíticos no feto e é possível que ocorram outras reações. Relataram-se casos de trombocitopenia ou icterícia neonatal com o tratamento tiazídico materno. Tiazidas são excretadas no leite humano e podem inibir a lactação. Reações adversas: Foram relatadas as seguintes reações adversas: Bronquite, faringite, sinusite, infecções do trato respiratório superior, infecções do trato urinário, sialadenite, eosinofilia, anemia aplástica, anemia hemolítica, depressão da medula óssea, leucopenia, neutropenia/agranulocitose, trombocitopenia, alergia, reações anafiláticas, perda do controle da diabete, hipercolesterolemia, hiperuricemia, hipopotassemia, causa ou aumento da depleção de volume, desequilíbrio eletrolítico, hiponatremia, anorexia, perda de apetite, hiperglicemia, ansiedade, depressão, inquietação, tontura, desmaio, insônia, escotomas, parestesia, distúrbios do sono, visão alterada, visão borrada temporariamente, xantopsia, vertigem, bradicardia, taquicardia, arritmias cardíacas, hipotensão, hipotensão postural, angiite necrotizante (vasculite), dispnéia, sofrimento respiratório (incluindo pneumonite e edema pulmonar), dor abdominal, diarréia, dispepsia, gastrite, dor de estômago, boca seca, flatulência, vômito, constipação, pancreatite, icterícia (icterícia hepatocelular ou colestática), eczema, aumento do suor, eritema, prurido, reações cutâneas do tipo lupus eritematoso, vasculite cutânea, reações de fotossensibilidade, erupções cutâneas, reativação do lupus eritematoso cutâneo, necrólise epidérmica tóxica, atralgia, artrose, dor nas costas, dor nas pernas, mialgia, cãibras nas pernas, sintomas de tendinite, fraqueza, espasmo muscular, nefrite intersticial, disfunção renal, glicosúria, impotência, sintomas de gripe, dor, dor no peito, perda da eficácia, febre. Investigações: Diminuição da hemoglobina, aumento
do ácido úrico, aumento na creatinina, aumento das enzimas hepáticas, aumento dos triglicérides. Assim como ocorre com outros antagonistas da angiotensina II, relataram-se casos isolados de angioedema, urticária e outras reações relacionadas. VENDA SOB PRESCRIÇÃO MÉDICA. - MS 1.0367.0134 Boehringer Ingelheim do Brasil Química e Farmacêutica Ltda. 